\title{
The Impact of Foreign Exchange and Oil Prices Shocks on the Novel Google Trend Based Index of Economic Policy Uncertainty: A Case of Developing Country
}

\author{
Umut Burak GEYIKKÇİ ${ }^{\text {bc }}$, Fatma İZMIRLİ ATAd, Lale YAKUPOĞLUe
}

\begin{abstract}
Economic policy uncertainty is one of the remarkable issues in the literature in recent years. Since there is no such index for Turkey, Google Trend based novel economic policy uncertainty index (EPU) was created for the first time by this study. Then the impact of oil price and exchange rate on economic policy uncertainty in Turkey were measured by ARDL bound test. As a result of the analysis, a cointegration relationship was found between all series. In addition, while oil prices have a significant effects on EPU in the long-run, the long-run effects of exchange rates have not been observed. In the short-run, it is seen that $4 \%$ of the deviations occurring in brent oil in the long-run improved in the next period. The short-run Granger causality relationships between the examined variables were detected by Block Exogenous Wald test. The results obtained show a mutual causality between the USD / TL exchange rate and the index in the short-run, while a unidirectional causality from Brent oil to EPU index has been detected.
\end{abstract}

Keywords

\section{Döviz ve Petrol Fiyat Şoklarının Yeni Google Trend Temelli Ekonomi Politikası Belirsizliği Endeksi Üzerindeki Etkisi: Gelişmekte Olan Ülke Örneği}

\begin{abstract}
Ekonomi politikası belirsizliği literatürde son yıllarda dikkat çeken konulardan biridir. Konu ile ilgili yapılan çalışmalar genellikle gelişmiş ülkeler üzerinde yoğunlaşmaktadır. Türkiye için böyle bir endeksin hesaplanmadığ için çalışma ile ilk kez bir endeks oluşturulmuştur. Ardından Türkiye'de petrol fiyatları ve döviz kurlarının ekonomi politikası belirsizliği üzerindeki etkisi ARDL sınırlar testi vasıtasıyla ölçülmüştür. Gerçekleştirilen analiz neticesinde tüm seriler arasında eşbütünleşme ilişkisi bulgulanmıştır. Ayrıca petrol fiyatlarının ekonomik politika belirsizliği üzerinde uzun dönemde etkili oldukları bulgulanırken döviz kurlarının uzun dönemde herhangi bir etkisi gözlemlenmemiştir. Kısa dönem de ise, brent petrolde uzun dönemde meydana gelen sapmaların \%4'ünün bir sonraki dönemde düzeldiği görülmektedir. İncelenen değişkenler arasındaki kısa dönemli Granger nedensellik ilişkilerini, Block Exojenite Wald testi vasıtasıyla test edilmiştir. Elde edilen sonuçlar, kısa dönemde Dolar/TL kuru ile endeks arasında karşılıklı bir nedensellik gösterirken, Brent petrolden endekse doğru da tek yönlü bir nedensellik bulgulanmışır.
\end{abstract}

Economic Policy Uncertainty Index Google Trend Based Index EPU

ARDL Bound Test

About Article

Received: 06.01.2021

Accepted: 10.05.2021

Doi: $10.18026 /$ cbayarsos. 855000

\footnotetext{
a This study was presented at the 13th International Congress of Social Sciences with Current Researches, held in Istanbul between 06-08 November 2020.

b Corresponding author: umutburak.geyikci@cbu.edu.tr

c Assoc. Prof. Dr. Manisa Celal Bayar University, Faculty of Business, Orchid ID: 0000-0002-4285-2151

d Assist. Prof. Dr. Manisa Celal Bayar University, Faculty of Economics and Administrative Science, Orchid ID: 0000-0003-2207-0010

e Assist. Prof. Dr. Manisa Celal Bayar University, Salihli Vocational School, Orchid ID: 0000-0001-5328-886X
}

Ekonomi Politikası Belirsizlik

Endeksi

Google Trende Dayalı Endeks

EPU

ARDL Sınırlar Testi

Makale Hakkında

Geliş Tarihi: 06.01.2021

Kabul Tarihi: 10.05.2021

Doi: 10.18026/cbayarsos. 855000 


\section{Introduction}

Oil importing developing countries such as Turkey, are extremely sensitive to changes in oil prices. Especially sudden price changes can create unexpected effects on the macroeconomic balances in the country. However, if the country also has a foreign trade deficit, exchange rates are considered as another important factor. For this reason, in a country with a high net oil importing and foreign trade deficit, both variables are expected to have effects that increase economic policy uncertainty separately and together. This issue has been studied in the literature by various researchers in different ways. From the pioneering studies (Hamilton, 1983) examining the relationship between oil prices and macroeconomic indicators concluded that the oil shocks in the USA after World War II had a significant impact on the economic recession in the country between 1948 and 1972. Afterwards, there have been many studies examining the relationship between oil prices and different macroeconomic indicators. Some of these are (Burbidge \& Harrison, 1984) (Kibritçioğlu \& Kibritçioğlu, 1999), (Zhang, 2008), (Elder, 2010), (Berument et al.2010) and (Musa, 2017). On the other hand, the relationships between foreign exchange prices and macroeconomic indicators are extremely important. Exchange rate plays an important role in growth, especially in developing countries. In their studies of 33 countries on the African continent from pioneering studies on the subject (Ghura \& Grennes, 1993) concluded that there was a negative correlation between the exchange rates and economic performance of the countries. Some other studies related to the subject in the literature are: (Maysami et al. 2004), (Basher \& Sadorsky, 2006), (Harms \& Kreschmann, 2009), (Gay, 2016). Previous studies made it necessary to measure the economic and financial uncertainty and the effects of uncertainty on different economic variables. Measurement of uncertainty in economics has been calculated in various ways by different authors in the literature. Different variables were used to represent uncertainty, but studies examining the relationship between economic uncertainty and other economic and financial variables are based on (Bernanke, 1983). In his study, Bernarke measured how and to what extent the durable consumption sector is affected under conditions of uncertainty. Using the daily volatility of share prices as an uncertainty index, (Bloom \& Bond, 2007) found that real option prices increased in times of uncertainty and it encouraged investors to behave more cautiously. Afterwards (Atta-Mensah, 2004) calculated the uncertainty index with 6 variables consisting of economic activity level, stock returns, inflation, exchange rate, long-run interest rate and short-run interest rate volatility and measured the effect of economic uncertainty on the money demand function and he concluded that the increase in uncertainty decreased the appetite of investors for risky assets, on the other hand, they increased the demand for money and caused an increase in the level of savings. In their studies on the subject (Alexopoulos \& Cohen, 2009) used two uncertainty indices to measure economic uncertainty, one of which is classical stock market volatility and the other, which consists of news published in the New York Times for the first time in the literature. They observed that unemployment, stagnation, production level and consumption decreased during periods of increased uncertainty. The current version of the economic policy uncertainty index (EPU) started with the study of (Baker et al. 2012). The authors created an economic policy uncertainty index based on the number of articles containing economic uncertainty about politics out of 5,000 newspaper articles in the USA. Later (Baker et al. 2016) developed the index by scanning over 12,000 newspaper articles in 10 
major newspapers in the USA, and then they began to calculate the index for 12 different countries. Afterwards, the authors started to publish the EPU for 26 countries, including the USA, through the website https://www.policyuncertainty.com/. Since the EPU was first published, there have been various studies investigating the relationship of uncertainty with different variables. From these studies, (Kang \& Ratti, 2013) investigated the impact of oil prices on the EPU and found that oil shocks had a significant impact on the EPU. In another study (Wang \& Wang, 2019) found that the changes in oil prices in the short and long run have a significant effect on the EPU. Some other studies examining the relationships between oil prices and EPU are (Kang \& Ratti, 2013), (Rehman, 2018) and (Das \& Kannadhasan, 2020). Exchange rates also have a significant economic impact in developing countries. The effect of both local and international currency shocks increasing the uncertainty is undeniable. Studies conducted in this context which are (Dai et al.2017) and (Olanipekun et al. 2019) reported that they found a significant causality between exchange rates and EPU and a positive correlation between variables. Some of the studies that examine the relationships between economic policy uncertainty index, oil prices and exchange rates are (Roubaud \& Arorui, 2018), (Mokni et al.2020), (Al-Yahyaee et al.2020) and (Chen, et al. 2019). Most of these studies have used EPU, which was created by (Baker, Bloom, \& Davis, 2016) and has been published regularly since 2017. Currently, Turkey does not exist in the index which calculates the uncertainty of 26 countries. Recently, internet search-based approaches have also been used to produce indices for the measurement of economic and political uncertainty (Bilgin et al. 2019). The first study to use Google Trend data to measure economic policy uncertainty was brought to literature by (Castelnuovo \& Tran, 2017). In this study, the authors searched the words they determined for the USA and Australia from the Google Trends database and determined their daily numbers and created an index from these numbers. They compared the index they created with both the economic policy uncertainty index of (Baker, Bloom, \& Davis, 2016) and different indices for both countries and obtained consistent results. Afterwards, some of the other studies using the EPU created by (Castelnuovo \& Tran, 2017) using Google data are as follows; (Bontempi et al.2018), (Donadelli \& Gerotto, 2019) and (Weinberg, 2020), (Geyikci, 2021).

In this study we translated the words into Turkish listed in the study of (Castelnuovo \& Tran, 2017) and created an index for Turkey by the way of searching into Google Trends. Afterwards, )we examined the short and long-run asymmetric relations and cointegration between oil prices, exchange rates and economic policy uncertainty, then we looked at the causal flows from shocks in oil prices and exchange rates to uncertainty indicators. Our study, which takes into account the effects of oil supply and demand shocks and exchange rate shocks on uncertainty, focuses on how the variables, which are analyzed from a general point of view, affect economic policy uncertainty in the short and long run and did not distinguish between positive and negative shocks. It also focuses on how the variables analyzed from a general perspective affect economic policy uncertainty in the short and long-run. In previous literature, the impact of oil price and exchange rates on EPU in Turkey or any other developing country has not been evaluated together. In this sense, this study will be the first for Turkey and net oil importing developing countries. 
Four hypothesis are tested in the study

Hypothesis 1: There is a cointegration relationship among EPU, exchange rate and oil prices.

Hypothesis 2: Oil prices have an effect on EPU

Hypothesis 3: Exchange rates have an effect on EPU.

Hypothesis 4 . There is a short-run causality relationship between EPU and oil prices and exchange rates.

The results of the study will help investors make investment decisions and portfolio diversification related to risk management, as well as have a significant impact on the decision of the assets allocation. On the other hand, it will be useful for political decision makers to manage the effects of oil and foreign exchange shocks on financial markets and to make correct political decisions. After this section, the study will continue as II. Material and Method, III. Findings, IV. Results and discussion.

\section{Material and Method}

There is no economic policy uncertainty index for Turkey. Therefore a novel index was created for Turkey benefiting from the index that was created by (Castelnuovo \& Tran, 2017), using Google trends data for the US and Australia. The words used in the study of the authors mentioned in this index were translated into Turkish and counted through Google trend for weekdays between 01.01.2020 and 09.09.2020. The index created has been used as the uncertainty index. Dollar / TL exchange rates and Brent oil barrel prices were taken from investing.com for the same period. While the cointegration relations between the analyzed series were examined through ARDL boundaries test, causality was evaluated by Granger Block Exogenity Wald Test method.

The econometric form of the model determined within the scope of the study was formed as follows;

Endekst $=\alpha+\beta_{1}$ Dövizt $_{t} \beta_{2}$ Petrol $_{t}+\varepsilon_{t}$

In the equation; $\alpha$ is the intersection point and $\beta_{1-} \beta_{2}$ are the coefficients of the explanatory variables. 


\section{Findings}

Table 1. contains descriptive statistics for time series.

Tablo 1. Descriptive Statistics

\begin{tabular}{llll} 
& Index & Brent Petrol & Dollar \\
\hline \hline Mean & 0,791701 & 42,61536 & 6,656692 \\
Median & 0,836194 & 42,94 & 6,8155 \\
Maximum & 2,860004 & 68,91 & 7,4848 \\
Minimum & $-3,056663$ & 19,33 & 5,8597 \\
Std. Dev. & 0,895542 & 12,01673 & 0,478105 \\
Skewness & $-0,886447$ & 0,240655 & $-0,249629$ \\
Kurtosis & 5,771438 & 2,441112 & 1,874765 \\
Sum & 141,7144 & 7628,15 & 1191,548 \\
Sum Sq. Dev. & 142,7552 & 25703,53 & 40,68801 \\
\hline Observations & 183,0000 & 183,0000 & 183,0000
\end{tabular}

By looking at the correlation matrix in Table 2, it has been determined that there is no multicollinearity problem among variables.

Tablo 2. Correlation Matrix

\begin{tabular}{lrrr} 
& Index & Brent Oil & Dollar/TL \\
\hline \hline Index & 1 & & \\
Brent Oil & $-0,4008$ & 1 & \\
Dollar/TL & 0,0769 & $-0,5399$ & 1 \\
\hline
\end{tabular}

For the ARDL boundary test to be used, although the series does not have the same level of stationarity condition, each series should be stationary at level or at the first difference, but neither should need a second or higher level of difference for stationarity. The Augmented Dickey-Fuller and Phillips Perron unit root test results at the level of all series are shown in Table 3. According to the results obtained, the $\mathrm{H} 0$ hypothesis was rejected because the Dollar/TL rate and Brent oil series contained unit roots, while the EPU did not contain unit roots with a margin of error of $1 \%$, concluded taht the series is stationary.

The values obtained from unit root test results allow us to easily state that there are no unit roots at the level for the EPU series, while for other series we need to check again with their first difference. 


\section{Unit Root Tests}

Tablo 3. Unit Root Tests (in level)

\begin{tabular}{|c|c|c|c|c|}
\hline Level & $\mathrm{ADF}$ & Result & $\mathrm{PP}$ & Result \\
\hline Dollar/TL & $-0,3323$ & Non-Stationary & $-0,3763$ & Non-Stationary \\
\hline Brent Oil & $-1,948667$ & Non-Stationary & $-1,9533$ & Non-Stationary \\
\hline Index & $-8,4323$ & Stationary $\mathrm{I}(0)$ & $-8,4323$ & Stationary $\mathrm{I}(0)$ \\
\hline \multirow[t]{3}{*}{ Critical Values } & $1 \%$ & $-4,042$ & $1 \%$ & $-4,04$ \\
\hline & $5 \%$ & $-3,45$ & $5 \%$ & $-3,449$ \\
\hline & $10 \%$ & $-3,151$ & $10 \%$ & $-3,15$ \\
\hline
\end{tabular}

After the results obtained in Table 3, ADF and PP unit root tests were applied again by taking the first differences of all series. The results show that all of the series are stationary in their first differences with $1 \%$ margin of error, and none of them need a second or higher order difference for stationarity.

\section{Tablo 4. Unit Root Tests (in first differences)}

\begin{tabular}{lrrrrr} 
First Difference & \multicolumn{1}{c}{ ADF } & & \multicolumn{2}{c}{ Result } & \multicolumn{2}{l}{ PP } & \multicolumn{2}{l}{ Sesult } \\
\hline \hline Dollar/TL & $-12,35674$ & & Stationary I(I) & $-12,35674$ & Stionary I(I) \\
Brent Oil & $-11,1521$ & & Stationary I(I) & $-11,21017$ & Stationary I(I) \\
Index & $-12,56306$ & Stationary I(I) & $-37,34906$ & Stationary I(I) \\
\hline Critical Values & $1 \%$ & $-4,042$ & $1 \%$ & $-4,04$ \\
& $5 \%$ & $-3,45$ & $5 \%$ & $-3,449$ \\
& $10 \%$ & $-3,151$ & $10 \%$ & $-3,15$ \\
\hline
\end{tabular}

According to the results obtained from Table 3 and Table 4, it has been observed that some series are stationary at level while some series are stationary in the first differences. If all series are not stationary at the same level, cointegration tests such as Johansen or Engle Granger cannot be used (Geyikçi, 2017). In cases where the series can be stationary at level and 1st differences but none of them need the 2nd or higher level for stationarity, the ARDL (Autoregressive Distributed Lag), which was introduced to the literature by Pesaran and Shin (1999) and Pesaran et al. (2001), is the most appropriate cointegration test (Ghildiyal, Pokhriyal, \& Mohan, 2015).

\section{ARDL Bound Test}

ARDL approach is applied as a Vector Autoregressive (VAR) model of $\mathrm{p}$. The following form was applied in the ARDL approach used in the cointegration test;

Endekst $_{t}=\alpha_{01}+\beta_{11}($ Endekst -1$)+\beta_{21}($ Dövizt-1 $)+\beta_{31}($ Petrol $\left.t-1)\right)+\sum_{i=1}^{p} \alpha_{1 i}($ Endekst -1$)++\sum_{i=1}^{p} \alpha_{2 i}\left(\right.$ Dövizt $-^{\prime}$ 1) $+\sum_{i=1}^{p} \alpha_{3 i}\left(\right.$ Petrol $\left._{-1}\right)+\varepsilon_{1 t}$ 
The index represents the currency and oil variables and $\varepsilon$ the error term in the equation. In the equation given above, the $\mathrm{H}_{0}$ hypothesis is that there is no cointegration, and the alternative hypothesis is that there is cointegration. The null hypothesis was tested by applying the $\mathrm{F}$ test.

Hence

$\mathrm{H}_{0}=\beta_{1 \mathrm{i}}=\beta_{2 \mathrm{i}}=\beta_{3 \mathrm{i}}=0$

$\mathrm{H} 1=\beta 1 \mathrm{i} \neq \beta 2 \mathrm{i} \neq \beta 3 \mathrm{i} \neq 0$

$\mathrm{i}=1,2,3$

Before applying the ARDL boundary test, it is a prerequisite to calculate the ARDL F statistic appropriately by selecting the appropriate lag order of the variables and to test whether there is cointegration between the variables. The calculation of the F-test is very sensitive to the selection of the lag length (Quattara, 2004). The appropriate lag length test results are given in Table 5. The lowest lag length for the Akaike information criterion was determined as the appropriate lag length. The optimal lag lenght was obtained at the 4 th lag.

Tablo 5. Lag Lenght Table

\begin{tabular}{rrrrrrr} 
Lag & LogL & LR & FPE & AIC & SC & HQ \\
\hline \hline 0 & $-1067,465$ & NA & 788,6137 & 15,18391 & $15.24665^{*}$ & 15,2094 \\
1 & $-1057,594$ & 19,18194 & 778,9656 & 15,17155 & 15,42251 & 15,27353 \\
2 & $-1050,385$ & 13,70287 & 799,1636 & 15,19695 & 15,63613 & 15,37542 \\
3 & $-1022,638$ & 51,55891 & 612,8476 & 14,93103 & 15,55843 & 15,18598 \\
4 & $-1004,664$ & $32.63359^{*}$ & $540.0630^{*}$ & $14.80374^{*}$ & 15,61936 & $15.13518^{*}$ \\
5 & $-997,9381$ & 11,92499 & 558,5338 & 14,836 & 15,83983 & 15,24392 \\
6 & $-989,3013$ & 14,9459 & 562,5442 & 14,84115 & 16,03321 & 15,32556 \\
7 & $-984,631$ & 7,883215 & 599,8299 & 14,90257 & 16,28284 & 15,46346 \\
8 & $-977,3866$ & 11,91994 & 617,2047 & 14,92747 & 16,49596 & 15,56485 \\
\hline
\end{tabular}

After the lag length is determined, according to the results in Table 6, it is seen that there is no problem in terms of autocorrelation, heterosthesis and normality in the series.

Tablo 6. Desctiptive Statistics

$$
X^{2} \quad \text { Prob. }
$$

\begin{tabular}{lll}
\hline \hline Breusch-Godfrey serial correlation test & 0,52951 & 0,5897 \\
Heteroskedasticity test & 0,05988 & 0,9419 \\
Jarque-Bera test & 1,20187 & 0,5483 \\
\hline
\end{tabular}

At this point, the F-test is applied to investigate long-run cointegration between variables. If the F statistic obtained in the cointegration relationship is below the given critical values, we conclude that there is no cointegration and if it is above these critical values, there is cointegration. The long-run cointegration relationship between the analyzed series can be seen in the Table 7. Since the obtained F statistic value exceeds the specified upper critical values, 
we can say that the series are cointegrated and in equilibrium in the long-run with a probability of error \%1.

\section{Tablo 7. ARDL Bound Test Results}

\begin{tabular}{lcc} 
Variables & F Statistic & \\
\hline \hline $\mathrm{f}($ Index/Dollar/TL, Brent Oil) & 24,1685 & \\
\hline & & \\
Critical Value Bounds & & \\
Significance & $\mathrm{I}(\mathrm{O})$ Bound & $\mathrm{I}(\mathrm{I})$ Bound \\
\hline $1 \%$ & 5,15 & 6,36 \\
$5 \%$ & 3,79 & 4,85 \\
$10 \%$ & 3,17 & 4,14 \\
\hline
\end{tabular}

The long-run equilibrium relationship between variables is calculated using the long-run ARDL $(4,1,4)$ model for EPU. The main purpose here is to examine the marginal effects of oil and exchange rate on EPU. Long-run coefficients are given in Table 8.

Endekst $==\alpha_{0}+\sum_{i=1}^{p} \alpha_{1 i}($ Endekst -1$)+\sum_{i=1}^{q} \alpha_{2 i}($ Döviz t-1 $)+\sum_{i=1}^{q} \alpha_{3 i}($ Petrol $\mathrm{t}-1)+\varepsilon_{\mathrm{t}}$

Long-run coefficients are given in Table 8 for the Index according to the above equation. While the obtained coefficients were significant for Brent oil at $1 \%$ significance level, they were insignificant in terms of exchange rate. These results conclude that there is no long-run causality between EPU and exchange rate, but there is a long-run causality between EPU and oil prices.

Tablo 8. ARDL $(4,1,4)$ Long Run Coefficients

\begin{tabular}{lccc} 
Variable & Coefficient & t-statistics & Prob. \\
\hline \hline C & 4,492375 & 2,55255 & 0,0116 \\
Dollar/TL & $-0,325933$ & $-1,429133$ & 0,1549 \\
Brent Oil & $-0,037217$ & $-4,092545$ & 0,0001 \\
\hline
\end{tabular}

The short-run parameters are estimated using the error correction term (ECT). In the error correction model, long-run causality occurs when the value of the error correction term (ECT) is negative and significant. Short-run causality is shown by the significance value of other regressor variables. The least squares (OLS) equation given below has been tested for shortrun causality within the framework of $\operatorname{ARDL}(1,2,3)$;

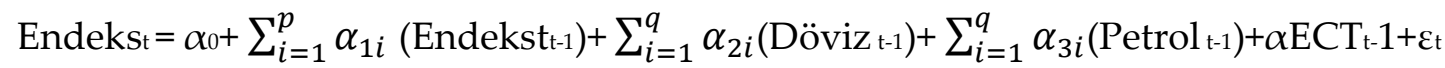

In the equation, $\alpha_{1 i}, \alpha_{2 i}, \alpha_{3 i}$ denote the short-run dynamic coefficients of the equilibrium convergence of the model and the correction speed is denoted by $\alpha$.

Short-run results are shown in Table 9. The results obtained are linked to long-run relationships as shown by the value and sign of the short-run dynamics, the delayed error correction term (ECT). The fact that the error correction term is negative and significant at the 
$1 \%$ significance level indicates the existence of a relationship between dependent variables and regressors. Since a negative and significant result was obtained in brent oil from the variables studied from this point of view, it was concluded that $4 \%$ of the deviations occurring in the long-run were in equilibrium for each day in the short-run.

Tablo 9. Short-run Error Correction Model Estimation Results

\begin{tabular}{lccl} 
Variable & Coefficient & t-statistics & Prob. \\
\hline \hline Dollar/TL & $-0,288658$ & $-2,070054$ & 0,0401 \\
Brent Oil & $-0,047472$ & $-8,009183$ & 0,0000 \\
ECT-1 & $-0,193922$ & $-2,794869$ & 0,0058 \\
R-square & 0,31312 & & \\
Adj. R-square & 0,300078 & & \\
F-statistics & 24,00857 & Prob(F-statistics) & 0,0000 \\
Durbin-Watson stat & 1,323018 & & \\
\hline
\end{tabular}

The obtained model also passed all tests in terms of diagnostic controls. Finding the DurbinWatson (DW) statistic as 1.323018 shows that there is no spurious regression problem. Table 10. shows the short-run Granger causality relationships between the variables. The results found a mutual causality relationship between EPU and dollar/TL exchange rate, while a oneway causality from Brent oil to EPU was found, but no causality from EPU to Brent oil was found.

Tablo 10. VAR Granger Causality/Block Exogeneity Wald Tests

\begin{tabular}{lcccll} 
& Index & Brent Oil & Dollar/TL & Causality direction & \\
\hline \hline Index & --- & 1,5527 & $5.0980^{* * *}$ & Index & Dollar/TL \\
Dollar/TL & $5.7831^{* *}$ & ---- & 0,2674 & Dollar/TL $\longrightarrow$ & Index \\
Brent Oil & $15.2837^{*}$ & 0,6825 & --- & Brent Oil $\longrightarrow$ Index \\
\hline
\end{tabular}

\section{Conclusion and Discussion}

This study examined the relationships between Brent oil prices, exchange rates and EPU based on daily data between 01.01.2020 and 09.09.2020. As part of the study, the index developed by (Castelnuovo \& Tran, 2017) was adapted and calculated by us for Turkey.

As a result of the analysis carried out;

Hypothesis 1: Long-run cointegration relationship between EPU, Brent oil and exchange rates has been found. (Olanipekun, 2019) found a cointegration relationship between exchange rates and EPU, (Yesuf \& Avc1, 2018) found a cointegration relationship between oil prices and EPU. In this respect, the results obtained are consistent with the literature. The findings from this study are important in terms of showing this relationship for the first time for Turkey.

Hypothesis 2: It has been found that oil prices have long-run effects on EPU. The findings obtained are similar to the findings of (Chen et al. 2019), (Kang \& Ratti, 2013) and (Antonakakis et al. 2014). On the other hand, when the short-run relationships between variables are examined, it is seen that $4 \%$ of the long-run deviations in Brent oil improve in the next period. 
Hypothesis 3: There is no long-run effect of exchange rates on EPU. Previous literature has focused on the effects of EPU on exchange rates. However, exchange rate shocks due to foreign economic or political factors may affect the country's EPU. In this context, the study results did not detect the existence of such an effect during the period studied in Turkey. As the exchange rate does not have a long-run relationship with the EPU, it is not possible to comment on short-run improvements.

Hypothesis 4: The short-run causality relationships between the examined variables were analyzed using the Granger / Block Exogenous Wald test. The results obtained show a mutual causality relationship between the exchange rate and EPU in the short run, similar to (Dai et al.2017) and (Olanipekun et al. 2019). In terms of the relationship between EPU and oil prices, different from the mutual causality relationship obtained in (Chen et al. 2019) and similar to the results obtained in (Yesuf \& Avc1, 2018), a unidirectional causality from Brent oil to EPU was found.

As a result of the analyzes carried out, the hypothesis that exchange rates and oil prices affect the EPU and that there is a mutual causality relationship between them could not be fully confirmed, and it was concluded that only oil prices among the variables affect the EPU. On the other hand, while causality is detected from foreign exchange and oil prices to EPU, a causality has been found from EPU to only the exchange rate.

According to the results, it has been concluded that although foreign exchange prices do not have an effect on the EPU, oil price shocks increase the uncertainty, so investors should monitor oil prices carefully, on the other hand, political decision makers should focus more on the measures that can be taken against the shocks in oil prices than foreign exchange prices.

In addition, for the first time, a Novel Economic Policy Uncertainty Index was created for Turkey, a developing, net oil importer country. It is important for the development of the study that this index will be used in future studies, allowing Turkey and other developing countries to examine the interactions between Economic Policy Uncertainty and different economic indicators.

\section{References}

Alexopoulos, M., \& Cohen, J. (2009). Uncertain Times, uncertain measures. Toronto: Department of Economics, University of Toronto.

Al-Yahyaee, K. H., Shahzad, S. H., \& Mensi, W. (2020). Tail dependence structures between economic policy uncertainty and foreign exchange markets: Nonparametric quantiles methods. International Economics, 161, 66-82.

Antonakakis, N., Chatziantoniou, I., \& Filis, G. (2014). Dynamic Spilovers of Oil Price Shocks and Economic Policiy Uncertainty. Energy Economics, 44, 433-447.

Atta-Mensah, J. (2004). Money Demand and Economic Uncertainty. Ottowa, Ontario, Canada K1A 0G9: Monetary and Financial Analysis Department Bank of Canade.

Baker, S., Bloom, N., \& Davis, S. (2012). Measuring Economic Policy Uncertainty. Chicago Booth Research Paper. 
Baker, S., Bloom, N., \& Davis, S. (2016). Maesuring Economic Policy Uncertanity. Quarterly Journal of Economics.

Basher, S. A., \& Sadorsky, P. (2006). Oil price risk and emerging stock markets. Global Finance Journal, 17, 224-251.

Bernanke, B. (1983). Irreversibility, Uncertainty, and Cyclical Investment. The Quarterly Journal of Economics, 98(1), 85-106.

Berument, M. H., Ceylan, N. B., \& Doğan, N. (2010). The Impact of Oil Price Shocks on the Economic Growth of Selected MENA Countries. The Energy Journal, 31(1), 149-176.

Bilgin, M. H., Demir, E., Gozgoz, E., Karabulut, G., \& Kaya, H. (2019). A novel index of macroeconomic uncertainty for Turkey based on Google-Trends. Economics Letter, 184. doi:https://doi.org/10.1016/j.econlet.2019.108601

Bloom, N. (2009). The Impact of Uncertainty Shocks. Econometrica, 77(3), 623-685.

Bloom, N., \& Bond, S. (2007). Uncertainty and Investment Dynamics. The Review of Economic Studies Limited, 74, 391-415.

Bontempi, M., Golinelli, R., \& Squadrani, M. (2018). Macroeconomic Unvertainty, Perception and Internet. Working Paper DSE No:1134.

Burbidge, J., \& Harrison, A. (1984). Testing for the Effects of Oil-Price Rises Using Vector Autoregressiona. International Economic Review, 25(2), 459-484.

Castelnuovo, E., \& Tran, T. D. (2017). Google It Up! A Google Trends-based Uncertainty Index for the United States and Australia. Munich Personal RePEc Archive. Melbourne: University of Melbourne and University of Padova, University of.

Chen, J., Jin, F., Ouyang, G., Ouyang, J., \& Wen, F. (2019). Oil Price Shocks, Economic Policy Uncertainty and Industrial Economic Growth in China. PLoS One, 14(5).

Dai, Y., Zhang, J.-w., Yu, X.-Z., \& LI, X. (2017). Causality Between Economic Policy Uncertainty and Exchange Rate in China with Considering Quantile Differences. Theortical and Applied Economics, XXIV(3(612)), 29-38.

Das, D., \& Kannadhasan, M. (2020). The asymmetric oil price and policy uncertainty shock exposure of emerging market sectoral equity returns: A quantile regression approach. International Review of Economics \& Finance, 69, 563-581.

Donadelli, M., \& Gerotto, L. (2019). Non-Macro Based Google Searches, Uncertainty, and Real Economic Activity. Res. Int. Bus. Finance, 48, 111-142.

Elder, J. (2010). Oil Price Uncertainty. J. Money Credit Bank, 42(6), 1137-1159.

Gay, R. D. (2016). Effect of Macroeconomic Variables on Stock Market Returns For Four Emerging Economies: Brazil, Russia, India, China. International Business \& Economics Research journal, 15(3), 119-126.

Geyikçi, U. B. (2017). Analysing of the Relation Between Stock Markets and Economic Growth in Turkey by ARDL Bound Test . Jounral of Business Research Turk, 9(3), 197-212.

Geyikçi, U. B. (2021). The Impact of Covid-19 and Crude Oil Price on Economic Policy Uncertainty; Evidence from an Emerging Market Economy, Jounral of Finance Letters, (115) , 103-118.

Ghildiyal, V., Pokhriyal, A. K., \& Mohan, A. (2015). Impact of Financial Deepening on Economic Growth in Indian Perspective: ARDL Bount Testing Approach to Coentegration. Asian Development Policy Review, 3(3), 49-60. 
Ghura, D., \& Grennes, T. (1993). The Ral Exchange Rate and Macroeconomic Performance in Sub-Saharan Africa. Journal of Development Economics, 42(1), 155-174.

Hamilton, J. D. (1983). Oil and the macroeconomy since World War II. J Political Econ. J Political Econ, 91(2), 228-248.

Harms, P., \& Kreschmann, M. (2009). Words, Deeds and Outcomes: A Survey on teh Growth Effects of Exchange Rate Regimes. Journal of Economic Surveys, 23(1), 139-164.

Kang, W., \& Ratti, R. A. (2013). Structural Oil Price Shoks an Policy Unvertanity. Economic Modelling, 35, 314-319.

Kibritçioğlu, A., \& Kibritçioğlu, B. (1999). Inflationary Effects of Increases in Prices of Improted Crude-Oil and Oil-Products in Turkey. Undersecretariat of Treasury Review and Research Journa.

Maysami, R. C., Howe, L. C., \& Hamza, M. A. (2004). Relationship between Macroeconomic Variables and Stock Market Indices: Cointegration Evidence from Stock Exchange of Singapore's All-S Sector Indices. Journal Pengurusan, 24, 47-77.

Mokni, K., Hammoudeh, S., Ajmi, A. N., \& Youssef, M. (2020). Does economic policy uncertainty drive the dynamic connectedness between oil price shocks and gold price? Resource Policy, 69(101819).

Musa, F. (2017). The Long Run Effects of Oil Price on Economic Growth The Case of Saudi Arabia. International ournal of Energy Economics and Policy, 7(6), 171-192.

Olanipekun, I. O., Güngör, H., \& Olasehinde-Williams, G. (2019). Unraveling the Causal Relationship Between Economic Policy Uncertainty and Exchange Market Pressure in BRIC Countries: Evidence From Bootstrap Panel Granger Causality. Sage Open, 1-13.

Olanipekun, I. O., Olasehinde-Williams, G., \& Güngör, H. (2019). Impact of Economic Policy Uncertainty on Exchange Market Pressure. Sage Open, 1-13.

Quattara, B. (2004). Foreign Aid and Fiscal Policy in Senegal. Unpiblished Manuscript. Manchester, U.K.: University of Manchester.

Rehman, M. U. (2018). Do Oil Shocks Predict Economic Policy Uncertainty. Physica A: Statistical Mechanics and Its Applications, 498, 123-136.

Roubaud, D., \& Arorui, M. (2018). Oil prices, excahnge rates and stock markets under uncertanity and regimeswitcing. Finance Research Letters, 27, 28-33.

Wang, Y., \& Wang, Y. (2019). The Impact of Oil Price Shocks on Economic Policy Uncertainty of China: Evidence from Nonlinear Analysis. Proceedings of the 2nd International Symposium on Social Science and Management Innovation (SSMI 2019). Advances in Social Science, Education and Humanities Research. doi:https://doi.org/10.2991/ssmi-19.2019.79

Weinberg, L. (2020). The Google Trend Uncertainty (GTU) Index: A Measure of Economic Policy Uncertainty in the EU Using Google Trends. Undergraduate Economic Review, 17(1).

Yesuf, A. J., \& Avcl, E. (2018). Economic Policy Uncertainty, Global Oil Price, Interest Rate, And Stock Market Returns - A Cointegration And Causality Analysis. International Review of Economics and Managemtn, 6(2), 21-42.

Zhang, D. (2008). Oil Shock and Economic Growth in japan: A Nonlinear Approach. Energy Economics, 30, 2374-2390. 